\title{
Cardiovascular Effects of Breathing 95 Percent Oxygen In Children With Congenital Heart Disease
}

\author{
ROBERT H. BEEKMAN, MD, ALBERT P. ROCCHINI, MD, and AMNON ROSENTHAL, MD
}

The hemodynamic effects of breathing $95 \%$ oxygen were evaluated in 26 children with congenital heart disease. Aortic, pulmonary arterial, right atrial, and pulmonary arterial wedge pressure, aortic and pulmonary artery oxygen saturation, and blood gas, cardiac index, and heart rate were measured in room air and after each patient had breathed $95 \%$ oxygen for $10(n=26)$ and $20(n=5)$ minutes. Measurements were repeated with the patient again breathing room air for $10(n=11)$ and $20(n=6)$ minutes. After 10 minutes of $95 \%$ oxygen, arterial partial pressure of oxygen increased from $85 \pm 13$ to $420 \pm 89$ torr $(p<0.001)$. Aortic mean pressure increased from $80 \pm 10$ to $83 \pm 10 \mathrm{~mm} \mathrm{Hg}$ (p $<0.01$ ), and systemic vascular resistance increased from $20 \pm 7$ to $26 \pm 8 \mathrm{U}(\mathbf{p}<\mathbf{0 . 0 0 1})$. The cardiac index decreased by $21 \%$ from $3.96 \pm 0.94$ to 3.12 \pm 0.74 liters $/ \mathrm{min} / \mathrm{m}^{2}(p<0.001)$ and the stroke index decreased by $11 \%$ (p <0.001). A $23 \%$ de- crease in oxygen consumption ( $p<0.001)$ was observed, and oxygen transport decreased from 763 \pm 179 to $600 \pm 161 \mathrm{ml} \mathrm{O} 0_{2} / \mathrm{min} / \mathrm{m}^{2}$ (p $<0.001$ ). Cardiac index, stroke index, and systemic vascular resistance did not return to normal until 20 minutes after cessation of oxygen breathing. To determine whether reflex bradycardia is responsible for these oxygen-induced hemodynamic changes, heart rate was kept constant by atrial pacing in a second group of 5 patients. In these children, significant decreases in cardiac index, stroke index, and oxygen consumption, and increases in systemic vascular resistance also occurred with $95 \%$ oxygen. Thus, in children with acyanotic congenital heart disease, hyperoxia increases aortic pressure and systemic vascular resistance and decreases cardiac index, stroke index, oxygen consumption, and oxygen transport.
The medical and surgical therapy of children with heart disease frequently includes administration of oxygen. The goal is to improve systemic oxygen delivery in patients with cyanosis, heart failure, or pulmonary edema. Previous studies have indicated, however, that oxygen itself may significantly alter cardiovascular hemodynamic function. In animals and in adults without heart disease, high inspired oxygen concentrations have been shown to increase systemic arterial pressure and systemic vascular resistance (SVR), and to decrease heart rate and cardiac index (CI). ${ }^{1-6}$ Similar studies have not been performed in children or in patients with heart disease. The present study was therefore designed to evaluate the hemodynamic effects of oxygen administration in children with acyanotic congenital heart disease.

From the Section of Pediatric Cardiology, Department of Pediatrics, C.S. Mott Children's Hospital, University of Michigan, Ann Arbor, Michigan. Manuscript received January 12, 1983; revised manuscript received April 4, 1983, accepted April 6, 1983.

Address for reprints: Albert P. Rocchini, MD, F1115, Box 66, C.S. Mott Children's Hospital, Ann Arbor, Michigan 48109.

\section{Methods}

The study involved 31 children with congenital heart disease who were undergoing diagnostic cardiac catheterization. There were 18 males and 13 females ranging in age from 0.2 to 15.5 years (mean 5.5 ). Twenty patients had previously undergone surgical repair of the following congenital heart defects: ventricular septal defect $(n=10)$, endocardial cushion defect $(n=3)$, patent ductus arteriosus $(n=3)$, D-transposition ( $n=2)$, tetralogy of Fallot $(n=1)$, and total anomalous pulmonary venous return $(n=1)$. The remaining patients, who not been operated on, had aortic stenosis $(\mathbf{n}=3)$, cardiomyopathy $(n=3)$, aortic regurgitation $(n=1)$, mitral regurgitation $(n=1)$, pulmonary stenosis $(n=1)$, L-transposition with pulmonary stenosis $(n=1)$, and primary pulmonary hypertension $(n=1)$. No patient had an intracardiac shunt documented at cardiac catheterization although several appeared to have a small intrapulmonary right-to-left shunt. Five patients (Table I: Patients 2, 12, 14, 20, 25) had congestive heart failure requiring treatment with digoxin and diuretics. Patients 2, 24, 25 and 26 had moderate to severe pulmonary artery hypertension (mean pulmonary pressure $\geq 0.5$ mean aurtic pressure). Patients 1, 2, 5 to 7,26 and 31 had multiple episodes of pneumonia and evidence on chest roentgenography of chronic pulmonary disease. 


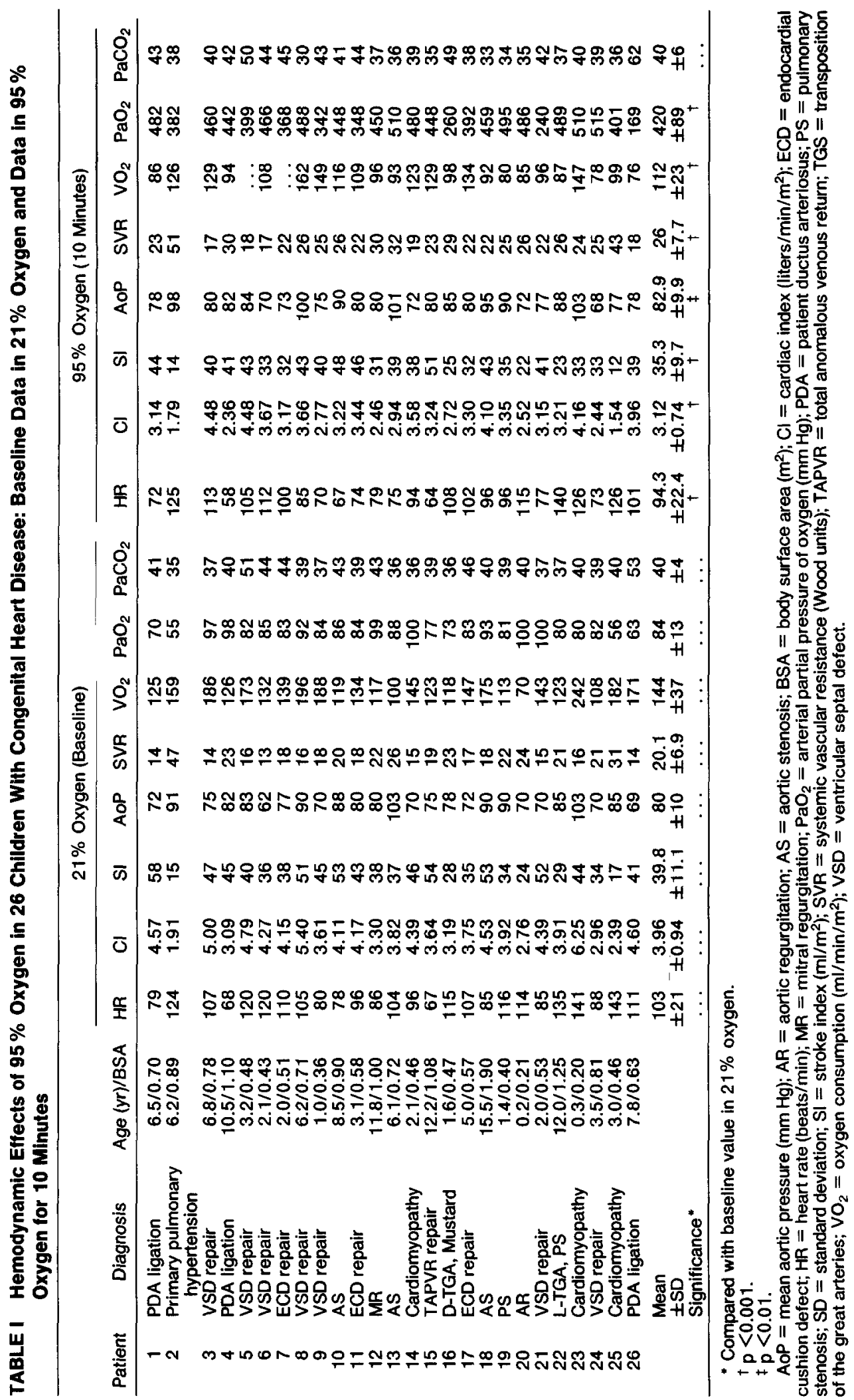


TABLE II Hemodynamic Effects of Breathing $95 \%$ Oxygen for 10 Versus 20 Minutes

\begin{tabular}{|c|c|c|c|c|c|c|c|c|c|c|c|c|c|c|c|c|c|c|c|c|c|}
\hline \multirow[b]{3}{*}{ Patient } & \multirow{2}{*}{\multicolumn{6}{|c|}{$21 \%$ Oxygen }} & \multirow[b]{3}{*}{$\mathrm{PaO}_{2}$} & \multicolumn{14}{|c|}{$95 \%$ Oxygen } \\
\hline & & & & & & & & \multicolumn{7}{|c|}{10 Minutes } & \multicolumn{7}{|c|}{20 Minutes } \\
\hline & HR & $\mathrm{Cl}$ & $\mathrm{Sl}$ & AoP & SVR & $\mathrm{VO}_{2}$ & & $\mathrm{HR}$ & $\mathrm{Cl}$ & SI & AoP & SVR & $\mathrm{VO}_{2}$ & $\mathrm{PaO}_{2}$ & $\mathrm{HR}$ & $\mathrm{Cl}$ & SI & AoP & SVR & $\mathrm{Vo}_{2}$ & $\mathrm{PaO}_{2}$ \\
\hline $\begin{array}{l}10 \\
11 \\
12 \\
16 \\
20\end{array}$ & $\begin{array}{r}78 \\
96 \\
86 \\
115 \\
114\end{array}$ & $\begin{array}{l}4.11 \\
4.17 \\
3.30 \\
3.19 \\
2.76\end{array}$ & $\begin{array}{l}53 \\
43 \\
38 \\
28 \\
24\end{array}$ & $\begin{array}{l}88 \\
80 \\
80 \\
78 \\
70\end{array}$ & $\begin{array}{l}20 \\
18 \\
22 \\
23 \\
24\end{array}$ & $\begin{array}{r}119 \\
134 \\
117 \\
118 \\
70\end{array}$ & $\begin{array}{r}86 \\
84 \\
99 \\
73 \\
100\end{array}$ & $\begin{array}{r}67 \\
74 \\
79 \\
108 \\
115\end{array}$ & $\begin{array}{l}3.22 \\
3.44 \\
2.46 \\
2.72 \\
2.52\end{array}$ & $\begin{array}{l}48 \\
46 \\
31 \\
25 \\
22\end{array}$ & $\begin{array}{l}90 \\
80 \\
80 \\
85 \\
72\end{array}$ & $\begin{array}{l}26 \\
22 \\
30 \\
29 \\
26\end{array}$ & $\begin{array}{r}116 \\
109 \\
96 \\
98 \\
85\end{array}$ & $\begin{array}{l}448 \\
348 \\
450 \\
260 \\
486\end{array}$ & $\begin{array}{r}67 \\
74 \\
78 \\
109 \\
114\end{array}$ & $\begin{array}{l}3.42 \\
3.40 \\
2.40 \\
2.87 \\
2.49\end{array}$ & $\begin{array}{l}51 \\
46 \\
31 \\
26 \\
22\end{array}$ & $\begin{array}{l}90 \\
78 \\
80 \\
85 \\
72\end{array}$ & $\begin{array}{l}25 \\
22 \\
31 \\
28 \\
28\end{array}$ & $\begin{array}{r}125 \\
94 \\
85 \\
87 \\
78\end{array}$ & $\begin{array}{l}488 \\
478 \\
472 \\
263 \\
492\end{array}$ \\
\hline $\begin{array}{l}\text { Mean } \\
\pm S D \\
\text { Signifi- } \\
\text { cance }\end{array}$ & $\begin{array}{r}98 \\
\pm 16 \\
\cdots\end{array}$ & $\begin{array}{r}3.50 \\
\pm 0.54 \\
\ldots\end{array}$ & $\begin{array}{r}37 \\
\pm 12 \\
\ldots\end{array}$ & $\begin{array}{l}79 \\
\pm 6 \\
\cdots\end{array}$ & $\begin{array}{r}22 \\
3 \\
\cdots\end{array}$ & $\begin{array}{r}112 \\
\pm 24 \\
\ldots\end{array}$ & $\begin{array}{r}88 \\
\pm 11\end{array}$ & $\begin{array}{r}89 \\
\pm 22 \\
\ldots\end{array}$ & $\begin{array}{r}2.85 \\
\pm 0.39 \\
\ldots\end{array}$ & $\begin{array}{r}35 \\
\pm 12 \\
\ldots\end{array}$ & $\begin{array}{r}81 \\
\pm 6 \\
\ldots\end{array}$ & $\begin{array}{r}27 \\
\pm 3 \\
\ldots\end{array}$ & $\begin{array}{r}101 \\
\pm 11 \\
\ldots\end{array}$ & $\begin{array}{r}398 \\
\pm 93 \\
\ldots\end{array}$ & $\begin{array}{r}88 \\
\pm 21 \\
\text { NS }\end{array}$ & $\begin{array}{r}2.92 \\
\pm 0.43 \\
\mathrm{NS}\end{array}$ & $\begin{array}{r}35 \\
\pm 13 \\
\text { NS }\end{array}$ & $\begin{array}{r}81.0 \\
\pm 7 \\
\text { NS }\end{array}$ & $\begin{array}{r}26 \\
\pm 4 \\
\text { NS }\end{array}$ & $\begin{array}{r}94 \\
\pm 18 \\
\text { NS }\end{array}$ & $\begin{array}{r}439 \\
\pm 98 \\
\dagger\end{array}$ \\
\hline
\end{tabular}

Before catheterization, each patient was premedicated with morphine sulfate $(0.15 \mathrm{mg} / \mathrm{kg})$ and diphenhydramine $(1.0$ $\mathrm{mg} / \mathrm{kg}$ ). After right and left heart catheterization had documented the underlying lesion, and before angiography, the study was performed. Baseline hemodynamic variables were measured with the patient breathing room air. Heart rate was determined from the electrocardiogram and averaged over a 10 -second period. Pressures were measured in the aorta, right atrium, pulmonary artery, and pulmonary artery wedge position. Aortic and pulmonary artery blood was sampled for blood gas (IL 813 analyzer) and oxygen saturation (reflection oximetry) measurements. All blood gas samples were collected in cold heparinized syringes, placed in ice, and analyzed within 5 minutes. Hemoglobin concentration was measured in an IL 182 co-oximeter, and oxygen-carrying capacity was calculated by multiplying the hemoglobin concentration by 1.36 . CI was measured by thermodilution technique (IL 701 thermodilution computer) and taken as the average of 3 determinations. In 5 patients, CI was also measured by dye dilution technique. Oxygen consumption $\left(\mathrm{VO}_{2}\right)$ was measured using a continuous flow-through system in room air, ${ }^{7}$ and was also calculated from thermodilution $\mathrm{CI}$ and oxygen content difference according to the Fick principle in both room air and $95 \%$ oxygen: $\mathrm{VO}_{2}$ $=$ thermal dilution cardiac output $(10 \times$ [oxygen capacity $X$ aortic saturation $+0.003 \times$ aortic $\left.\mathrm{PO}_{2}\right]$ ) - (oxygen capacity
$X$ pulmonary artery saturation $+0.003 \times$ pulmonary artery $\mathrm{PO}_{2}$ ), where $\mathrm{PO}_{2}=$ partial pressure of oxygen. Core temperature was measured with thermodilution thermistor situated in the main pulmonary artery.

After acquisition of baseline data, each patient was administered 95\% oxygen. This was the highest inspired oxygen concentration that could be reliably administered by a hood system. Inspired oxygen concentration $\left(\mathrm{F}_{\mathrm{I}} \mathrm{O}_{2}\right)$ was determined using an Applied Electrochemistry oxygen analyzer. Measurements of heart rate, pressures, blood gases and saturations, $\mathrm{CI}$, and $\mathrm{VO}_{2}$ were made as just described after oxygen breathing for 10 minutes $(n=26)$ and 20 minutes $(n=5)$. Hemodynamic measurements were then repeated with the patient once again breathing room air for 10 minutes $(n=11)$ and 20 minutes $(\mathrm{n}=6)$.

To evaluate the hemodynamic significance of reflex bradycardia during oxygen breathing, heart rate was kept constant by atrial pacing (rate 5 beats/min above the spontaneous sinus rate) in 5 patients. Hemodynamic measurements were made in room air and after breathing $95 \%$ oxygen for 10 minutes as described previously.

Data were evaluated for significance using the two-tailed $t$ test for paired observations. All values are expessed as mean \pm standard deviation.

TABLE III Duration of Oxygen-Induced Hemodynamic Changes

\begin{tabular}{|c|c|c|c|c|c|c|c|c|c|c|c|c|}
\hline \multirow[b]{2}{*}{ Patient } & \multicolumn{6}{|c|}{$21 \%$ Oxygen (Baseline) } & \multicolumn{6}{|c|}{$95 \%$ Oxygen (10 Minutes) } \\
\hline & HR & $\mathrm{Cl}$ & SI & AoP & SVR & $\mathrm{VO}_{2}$ & HR & $\mathrm{Cl}$ & SI & AoP & SVR & $\mathrm{VO}_{2}$ \\
\hline $\begin{array}{r}10 \\
12 \\
14 \\
18 \\
22 \\
25 \\
2 \\
5 \\
16 \\
17 \\
19 \\
21\end{array}$ & $\begin{array}{r}78 \\
86 \\
96 \\
85 \\
135 \\
143 \\
124 \\
120 \\
115 \\
107 \\
116 \\
85\end{array}$ & $\begin{array}{l}4.11 \\
3.30 \\
4.39 \\
4.53 \\
3.91 \\
2.39 \\
1.91 \\
4.79 \\
3.19 \\
3.75 \\
3.92 \\
4.39\end{array}$ & $\begin{array}{l}53 \\
38 \\
46 \\
53 \\
29 \\
17 \\
15 \\
30 \\
28 \\
35 \\
34 \\
52\end{array}$ & $\begin{array}{l}88 \\
80 \\
70 \\
90 \\
85 \\
85 \\
91 \\
83 \\
78 \\
72 \\
90 \\
70\end{array}$ & $\begin{array}{l}20 \\
22 \\
15 \\
19 \\
21 \\
31 \\
47 \\
16 \\
23 \\
17 \\
22 \\
15\end{array}$ & $\begin{array}{l}119 \\
117 \\
145 \\
175 \\
123 \\
182 \\
159 \\
173 \\
118 \\
147 \\
113 \\
143\end{array}$ & $\begin{array}{r}67 \\
79 \\
94 \\
96 \\
140 \\
126 \\
125 \\
105 \\
108 \\
102 \\
96 \\
77\end{array}$ & $\begin{array}{l}3.22 \\
2.46 \\
3.58 \\
4.10 \\
3.21 \\
1.54 \\
1.79 \\
4.48 \\
2.72 \\
3.30 \\
3.35 \\
3.15\end{array}$ & $\begin{array}{l}48 \\
31 \\
38 \\
43 \\
23 \\
12 \\
14 \\
43 \\
25 \\
31 \\
35 \\
41\end{array}$ & $\begin{array}{l}90 \\
80 \\
72 \\
95 \\
88 \\
77 \\
98 \\
84 \\
85 \\
80 \\
90 \\
77\end{array}$ & $\begin{array}{l}26 \\
30 \\
19 \\
22 \\
26 \\
43 \\
51 \\
18 \\
29 \\
22 \\
25 \\
22\end{array}$ & $\begin{array}{r}116 \\
96 \\
123 \\
92 \\
85 \\
99 \\
126 \\
\because 98 \\
134 \\
80 \\
96\end{array}$ \\
\hline $\begin{array}{l}\text { Mean } \\
\pm S D \\
\text { Signifi- } \\
\text { cance }\end{array}$ & $\begin{array}{r}107 \\
\pm 21\end{array}$ & $\begin{array}{r}3.71 \\
\pm 0.83\end{array}$ & $\begin{array}{r}37 \\
\pm 13\end{array}$ & $\begin{array}{r}82 \\
\pm 8\end{array}$ & $\begin{array}{l}22 \\
\pm 9\end{array}$ & $\begin{array}{r}143 \\
\pm 25.1\end{array}$ & $\begin{array}{r}101 \\
21\end{array}$ & $\begin{array}{r}3.07 \\
\pm 0.81\end{array}$ & $\begin{array}{r}32.0 \\
\pm 11.4\end{array}$ & $\begin{array}{r}85 \\
\pm 8\end{array}$ & $\begin{array}{r}28 \\
\pm 10\end{array}$ & $\begin{array}{r}104 \\
\pm 18\end{array}$ \\
\hline
\end{tabular}

- Compared with baseline value in $21 \% \mathrm{O}_{2}$.

Abbreviations as in Table I. 


\section{Results}

After 10 minutes of breathing $95 \%$ oxygen, mean arterial $\mathrm{PO}_{2}$ increased from $86 \pm 13$ to $420 \pm 89$ torr (p $<0.001$ ) and arterial oxygen content increased from 17.0 \pm 1.9 to $18.7 \pm 2.0 \mathrm{ml} / 100 \mathrm{ml}(\mathrm{p}<0.001)$. There was a slight increase in these values after 20 minutes of oxygen breathing. The increase in mean arterial $\mathrm{PO}_{2}$ to only (420 \pm 89 torr) after 10 minutes of breathing $95 \%$ oxygen suggests that some degree of intrapulmonary rightto-left shunting was present in our patients. Arterial pH, $\mathrm{PCO}_{2}$, and temperature did not change during the study.

Significant hemodynamic effects were noted after 10 minutes of oxygen breathing (Table I). Heart rate decreased from $103 \pm 21$ to $94 \pm 22$ beats $/ \mathrm{min}(\mathrm{p}<0.001)$. Mean systemic arterial pressure increased from $80 \pm 11$ to $83 \pm 10 \mathrm{~mm} \mathrm{Hg}$ (p <(1.01), and mean pulmonary arterial pressure decreased from $24 \pm 12$ to $22 \pm 11 \mathrm{~mm}$ $\mathrm{Hg}(\mathrm{p}<0.01)$. Mean right atrial pressure increased from $5 \pm 2$ to $6 \pm 2 \mathrm{~mm} \mathrm{Hg}$ (p<0.01), while the small observed increase in pulmonary arterial wedge pressure from $10 \pm 5$ to $11 \pm 5 \mathrm{~mm} \mathrm{Hg}(\mathrm{p}=0.15)$ did not reach statistical significance.

CI measured by thermodilution technique was diminished in every patient after 10 minutes in $95 \%$ oxygen. Mean CI decreased by $21 \%$ from $3.96 \pm 0.94$ to 3.12 $\pm 0.74 \mathrm{liters} / \mathrm{min} / \mathrm{m}^{2}(\mathrm{p}<0.001)$. Stroke index decreased by $11 \%$ from $39.9 \pm 11.1$ to $35.5 \pm 9.7 \mathrm{ml} / \mathrm{m}^{2}(\mathrm{p}<0.001)$. In 5 patients, $\mathrm{CI}$ determined by dye dilution did not differ significantly from simultaneous thermodilution measurements.

Oxygen breathing resulted in a significant elevation of SVR from $20.1 \pm 6.9$ to $25.5 \pm 7.7 \mathrm{U}(\mathrm{p}<0.001)$. Pulmonary vascular resistance did not change significantly.

$\mathrm{VO}_{2}$ was calculated from thermodilution cardiac output according to the Fick principle. In room air, this calculated $\mathrm{VO}_{2}$ did not differ significantly from $\mathrm{VO}_{2}$ measured by a continuous flow-through system (150 \pm
26 versus $156 \pm 24 \mathrm{ml} / \mathrm{min} / \mathrm{m}^{2}$, respectively). After 10 minutes of breathing $95 \%$ oxygen, $\mathrm{VO}_{2}$ decreased by $24 \%$ ( $p<0.001)$ (Table I). Oxygen transport, the product of arterial oxygen content and cardiac output, decreased as well, from $762.9 \pm 179.4$ to $600.2 \pm 161.3 \mathrm{ml} \mathrm{O} / \mathrm{min} /$ $\mathrm{m}^{2}(\mathrm{p}<0.001)$.

After 20 minutes of oxygen breathing, no further hemodynamic changes were noted. The data in Table II indicate that hemodynamic measurements made after 20 minutes did not differ significantly from those made after 10 minutes of breathing $95 \%$ oxygen. Thus, oxygen seems to exert its major cardiovascular effects within 10 minutes. Ten minutes after cessation of oxygen breathing, however, all values had not returned to baseline (Table III). CI, stroke volume, oxygen transport, and $\mathrm{VO}_{2}$ remained significantly depressed and SVR remained elevated $(p<0.01)$. These and all other hemodynamic parameters returned to normal after 20 minutes after oxygen breathing.

The effects of breathing $95 \%$ oxygen on the 5 patients with congestive heart failure are presented in the Figure 1. These data are highlighted since the hemodynamic effects of oxygen in such patients may be of particular clinical relevance. When compared with the 21 patients without failure, oxygen decreased CI and stroke volume and increased SVR in the 5 children with congestive failure. CI decreased from $2.95 \pm 0.95$ to $2.38 \pm 0.79$ liters $/ \mathrm{min} / \mathrm{m}^{2}(p<0.05)$, stroke index decreased from 28.1 \pm 13.4 to $23.6 \pm 11.1 \mathrm{ml} / \mathrm{m}^{2}(\mathrm{p}<0.05)$, and SVR increased from $27.7 \pm 11.8$ to $34.0 \pm 13.1 \mathrm{U}(\mathrm{p}<0.05)$.

To evaluate the role played by reflex bradycardia during oxygen breathing, heart rate was held constant by atrial pacing in 5 patients. Hemodynamic values measured before oxygen and after breathing $95 \%$ oxygen for 10 minutes are presented in Table IV. CI and stroke index both decreased by $12 \%(\mathrm{p}<0.05) . \mathrm{VO}_{2}$ also decreased from $146.2 \pm 42.2$ to $97.0 \pm 12.0 \mathrm{ml} / \mathrm{min} / \mathrm{m}^{2}$ (p $<0.05$ ). SVR increased in oxygen from $22.8 \pm 5.1$ to 26.4 $\pm 5.5 \mathrm{U}(\mathrm{p}<0.05)$.

TABLE III (Continued)

\begin{tabular}{|c|c|c|c|c|c|c|c|c|c|c|c|c|}
\hline \multirow[b]{3}{*}{ Patient } & \multicolumn{12}{|c|}{ Return to $21 \%$ Oxygen } \\
\hline & \multicolumn{6}{|c|}{ to Minutes } & \multicolumn{6}{|c|}{20 Minutes } \\
\hline & HR & Cl & SI & AoP & SVR & $\mathrm{VO}_{2}$ & HR & $\mathrm{Cl}$ & SI & AoP & SVR & $\mathrm{VO}_{2}$ \\
\hline \multirow{2}{*}{$\begin{array}{r}10 \\
12 \\
14 \\
18 \\
22 \\
25 \\
2 \\
5 \\
16 \\
17 \\
19 \\
21\end{array}$} & $\begin{array}{r}79 \\
92 \\
96 \\
94 \\
142 \\
137\end{array}$ & $\begin{array}{l}3.88 \\
2.80 \\
3.91 \\
4.26 \\
4.24 \\
1.80\end{array}$ & $\begin{array}{l}49 \\
30 \\
41 \\
45 \\
30 \\
13\end{array}$ & $\begin{array}{r}100 \\
80 \\
70 \\
90 \\
100 \\
72\end{array}$ & $\begin{array}{r}26 \\
17 \\
18 \\
22 \\
\ldots\end{array}$ & $\begin{array}{l}118 \\
110 \\
130 \\
148 \\
133 \\
134\end{array}$ & $\begin{array}{l}\ldots \\
\ldots \\
\cdots \\
\ldots \\
\ldots \\
\cdots\end{array}$ & $\begin{array}{l}\ldots \\
\cdots \\
\cdots \\
\cdots \\
\cdots\end{array}$ & $\begin{array}{l}\cdots \\
\cdots \\
\cdots \\
\cdots \\
\cdots\end{array}$ & $\begin{array}{l}\cdots \\
\cdots \\
\cdots \\
\cdots \\
\cdots\end{array}$ & $\begin{array}{l}\ldots \\
\ldots \\
\ldots \\
\ldots \\
\cdots \\
\cdots\end{array}$ & $\begin{array}{l}\cdots \\
\cdots \\
\cdots \\
\cdots \\
\cdots\end{array}$ \\
\hline & $\begin{array}{r}116 \\
112 \\
107 \\
105 \\
84\end{array}$ & $\begin{array}{l}3.60 \\
2.76 \\
3.51 \\
3.38 \\
3.64\end{array}$ & $\begin{array}{l}31 \\
25 \\
33 \\
32 \\
43\end{array}$ & $\begin{array}{l}\ddot{66} \\
78 \\
72 \\
90 \\
66\end{array}$ & $\begin{array}{l}10 \\
26 \\
18 \\
26 \\
17\end{array}$ & $\begin{array}{l}118 \\
102 \\
145 \\
108 \\
124\end{array}$ & $\begin{array}{r}130 \\
120 \\
115 \\
107 \\
110 \\
85\end{array}$ & $\begin{array}{l}1.93 \\
4.79 \\
3.19 \\
3.85 \\
3.75 \\
4.33\end{array}$ & $\begin{array}{l}15 \\
40 \\
28 \\
36 \\
34 \\
51\end{array}$ & $\begin{array}{l}90 \\
66 \\
78 \\
72 \\
90 \\
68\end{array}$ & $\begin{array}{l}45 \\
12 \\
23 \\
16 \\
23 \\
14\end{array}$ & $\begin{array}{l}164 \\
157 \\
124 \\
159 \\
120 \\
148\end{array}$ \\
\hline $\begin{array}{l}\text { Mean } \\
\pm S D \\
\text { Signifi- } \\
\text { cance* }\end{array}$ & $\begin{array}{r}106 \\
\pm 20 \\
\text { NS }\end{array}$ & $\begin{array}{r}3.43 \\
\pm 0.69 \\
t\end{array}$ & $\begin{array}{r}33.8 \\
\pm 10.2 \\
\ddagger\end{array}$ & $\begin{array}{r}80 \\
\pm 13 \\
\text { NS }\end{array}$ & $\begin{array}{r}21 \\
+4.2 \\
+\end{array}$ & $\begin{array}{r}124 \\
\pm+5 \\
t\end{array}$ & $\begin{array}{r}111.2 \\
\pm 15.2 \\
\text { NS }\end{array}$ & $\begin{array}{r}3.64 \\
\pm 0.84 \\
\text { NS }\end{array}$ & $\begin{array}{r}34 \\
\pm 12.1 \\
\mathrm{NS}\end{array}$ & $\begin{array}{r}77 \\
\pm 11 \\
\text { NS }\end{array}$ & $\begin{array}{r}22 \\
\pm 11.8 \\
\text { NS }\end{array}$ & $\begin{array}{r}145 \\
\pm 19 \\
\text { NS }\end{array}$ \\
\hline
\end{tabular}

$t_{p}<0.01$
$t_{p}<0.05$ 

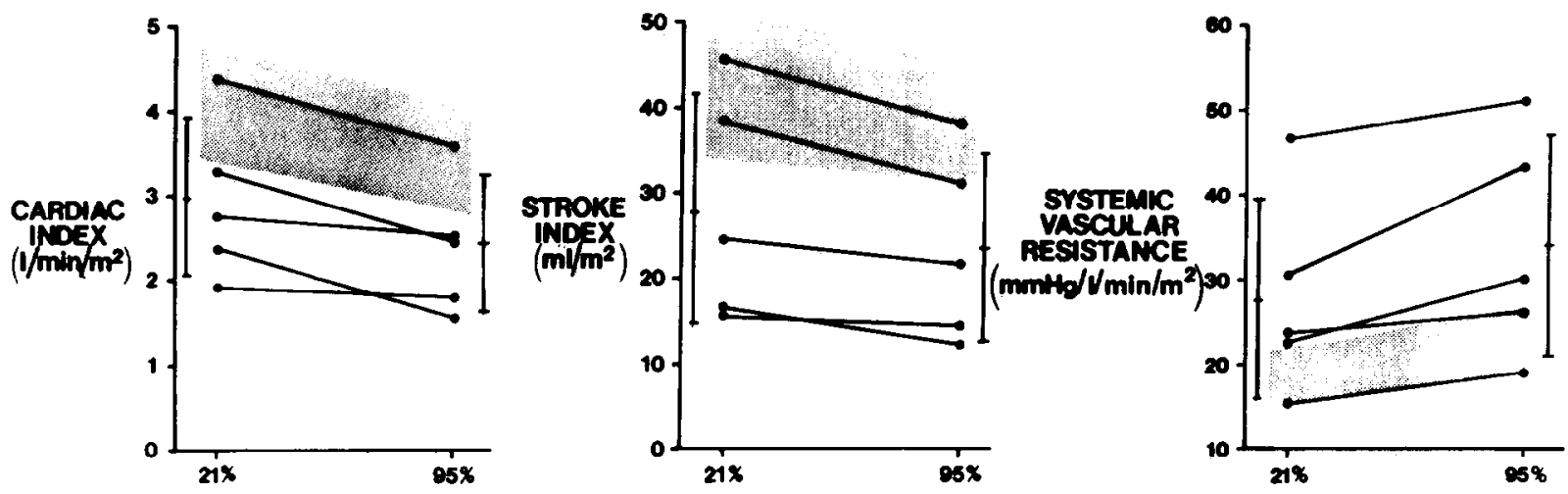

INSPIAED OXYGEN CONCENTRATION

FIGURE 1. Cardiovascular effects of oxygen.

\section{Discussion}

This study documents significant hemodynamic changes induced by the breathing of $95 \%$ oxygen in children with congenital heart disease. Oxygen breathing increased SVR and arterial pressure, and decreased heart rate, $\mathrm{CI}$, and stroke volume. A marked decrease in $\mathrm{VO}_{2}$ was observed as well. These hemodynamic changes occurred in all patients regardless of cardiac diagnosis or the presence of intrapulmonary right-to-left shunting.

Several studies have documented an increase in SVR induced by hyperoxia. ${ }^{1-6,8}$ Eggers et al ${ }^{1}$ noted a $22 \%$ increase in 10 healthy adults breathing $100 \%$ oxygen for 20 minutes. Torbati et al, ${ }^{5}$ studying rats exposed to high oxygen tension, concluded that the elevated SVR was due primarily to vasoconstriction in large muscle groups. This is consistent with observations, using venous $o c-$ clusion plethysmography, that forearm blood flow is reduced by $18.9 \%$ in adults breathing oxygen at $2 \mathrm{~atm}$ pressure. ${ }^{8}$ Hyperoxia has been shown to affect SVR by increasing precapillary sphincter tone. ${ }^{9}$ The mechanism by which oxygen increases SVR remains unclear, however. A direct constrictor effect of oxygen on arteriolar smooth muscle and chemoreceptor-mediated reflex vasoconstriction have been postulated. ${ }^{20}$ The observa- tion that significant hemodynamic effects persist for 20 minutes (40 minutes in Egger et al's study ${ }^{1}$ ) despite normalization of arterial oxygen content suggests that a circulating vasoconstrictor substance may also be involved in mediating the cardiovascular response to hyperoxia.

A decrease in heart rate during oxygen breathing has also been reported by a number of investigators. ${ }^{1-3,5,11,12}$ Daly and Bondurant ${ }^{2}$ demonstrated an inverse linear relationship between heart rate and inspired oxygen concentration in 15 normal adults. After administration of atropine, however, heart rate did not decrease in response to high inspired oxygen concentrations. Thus, it appears that hyperoxia-induced bradycardia may be mediated by the baroreflex in response to an increase in arterial pressure.

CI decreases in response to hyperoxia. ${ }^{1-6,13}$ Our data indicate that this is due to the combined effects of a decrease in both heart rate and stroke volume. CI decreased by $21 \%$ after 10 minutes of breathing $95 \%$ oxy. gen. In the 5 patients whose heart rates were kept constant by atrial pacing, $\mathrm{CI}$ decreased by $12 \%$, entirely the consequence of a diminished stroke volume. This $12 \%$ decrease in stroke volume was almost identical in magnitude to that observed in the 26 nonpaced patients.

TABLE IV Hemodynamic Effects of Breathing $95 \%$ Oxygen in 5 Children During Atrlal Pacing

\begin{tabular}{|c|c|c|c|c|c|c|c|c|c|c|c|c|c|c|c|c|c|c|}
\hline \multirow[b]{2}{*}{ Patient } & \multirow[b]{2}{*}{ Diagnosis } & \multirow{2}{*}{$\begin{array}{c}\text { Age } \\
\text { (yr) }\end{array}$} & \multicolumn{8}{|c|}{$21 \%$ Oxygen (Baseline) } & \multicolumn{8}{|c|}{$95 \%$ Oxygen (10 Minutes) } \\
\hline & & & HA & $\mathrm{Cl}$ & SI & AOP & SVR & $\mathrm{VO}_{2}$ & $\mathrm{PaO}_{2}$ & $\mathrm{PaCO}_{2}$ & HR & $\mathrm{Cl}$ & SI & AoP & SVR & $\mathrm{VO}_{2}$ & $\mathrm{PaO}_{2}$ & $\mathrm{PaCO}_{2}$ \\
\hline 27 & $\begin{array}{c}\text { Mustard repair } \\
\text { of D-TGA }\end{array}$ & 2.0 & 85 & 3.24 & 38 & 68 & 20 & 132 & 94 & 39 & 85 & 2.80 & 33 & 80 & 27 & 90 & 480 & 37 \\
\hline $\begin{array}{l}28 \\
29 \\
30 \\
31\end{array}$ & $\begin{array}{l}\text { VSO repair } \\
\text { TOF repair } \\
\text { VSD repair } \\
\text { VSD repair }\end{array}$ & $\begin{array}{r}12.0 \\
5.0 \\
10.0 \\
1.4\end{array}$ & $\begin{array}{r}105 \\
125 \\
95 \\
115\end{array}$ & $\begin{array}{l}3.48 \\
4.71 \\
3.50 \\
3.48\end{array}$ & $\begin{array}{l}33 \\
38 \\
37 \\
30\end{array}$ & $\begin{array}{r}97 \\
97 \\
115 \\
69\end{array}$ & $\begin{array}{l}26 \\
20 \\
30 \\
18\end{array}$ & $\begin{array}{r}97 \\
213 \\
140 \\
149\end{array}$ & $\begin{array}{l}98 \\
96 \\
88 \\
68\end{array}$ & $\begin{array}{l}38 \\
33 \\
38 \\
42\end{array}$ & $\begin{array}{r}105 \\
125 \\
95 \\
115\end{array}$ & $\begin{array}{l}3.32 \\
3.91 \\
2.93 \\
3.30\end{array}$ & $\begin{array}{l}32 \\
31 \\
31 \\
29\end{array}$ & $\begin{array}{r}108 \\
93 \\
110 \\
72\end{array}$ & $\begin{array}{l}29 \\
23 \\
33 \\
19\end{array}$ & $\begin{array}{r}85 \\
103 \\
91 \\
115\end{array}$ & $\begin{array}{l}390 \\
420 \\
391 \\
248\end{array}$ & $\begin{array}{l}38 \\
35 \\
39 \\
44\end{array}$ \\
\hline $\begin{array}{l}\text { Mean } \\
\pm S D \\
\text { Signifi- } \\
\text { Cance }\end{array}$ & $\cdots$ & & $\begin{array}{r}105 \\
\pm 16 \\
\cdots\end{array}$ & $\begin{array}{r}3.68 \\
\pm 0.59 \\
\ldots\end{array}$ & $\begin{array}{r}35 \\
\pm 3 \\
\ldots\end{array}$ & $\begin{array}{r}89.2 \\
\pm 20.3 \\
\ldots\end{array}$ & $\begin{array}{l}23 \\
\pm 5 \\
\cdots\end{array}$ & $\begin{array}{r}146 \\
\pm 42 \\
\cdots\end{array}$ & $\begin{array}{r}89 \\
\pm 12 \\
\ldots\end{array}$ & $\begin{array}{l}38 \\
\pm 3 \\
\cdots\end{array}$ & $\begin{array}{r}105 \\
\pm 16 \\
\text { NS }\end{array}$ & $\begin{array}{r}3.25 \\
\pm 0.43 \\
t\end{array}$ & $\begin{array}{r}31 \\
\pm 2 \\
+\end{array}$ & $\begin{array}{r}93 \\
\pm 17 \\
\text { NS }\end{array}$ & $\begin{array}{r}26 \\
\pm 6 \\
\dagger\end{array}$ & $\begin{array}{r}97 \\
+12\end{array}$ & $\begin{array}{r}386 \\
+85\end{array}$ & $\begin{array}{r}39 \\
\pm 3 \\
\ldots\end{array}$ \\
\hline
\end{tabular}

- Compared with baseline value in $21 \% \mathrm{O}_{2}$

$+p<0.05$.

NS $=$ not significant at $p<0.05$

Abbreviations as in Table I. 
Thus, the decrease in CI during oxygen breathing is due to a decrease in stroke volume as well as heart rate. In contrast, Daly and Bondurant ${ }^{2}$ failed to demonstrate a statistically significant, decrease in stroke volume in 6 patients during oxygen breathing when reflex bradycardia was abolished by atropine administration. Their data show, however, that stroke volume did decrease in 4 subjects and was unchanged in 2 .

The oxygen-induced decrease in stroke volume may be due to multiple factors. First, it may reflect an increased SVR and left ventricular afterload. This factor may be of particular significance in children with heart disease. Second, the decrease in stroke volume may relate to myocardial depression by hyperoxia. Several studies have documented diminished ventricular function in animals exposed to high oxygen concentrations. ${ }^{10-16}$ Kioschos et, al, ${ }^{15}$ for example, found a $14 \%$ decrease in the first derivative of left ventricular pressure in dogs during hyperbaric oxygenation at $3.6 \mathrm{~atm}$ for 15 minutes. Finally, hyperoxia has been shown to decrease coronary artery blood flow, ${ }^{14,17}$ which may further compromise myocardial function.

The hemodynamic response to hyperoxia may be of particular clinical relevance in children with congestive heart failure and already compromised ventricular performance. Figure 1 illustrates some of the hemodynamic changes induced by breathing $95 \%$ oxygen for 10 minutes in 5 children with heart failure. In room air, these children already had a mean CI and stroke index well below, and a mean SVR well above the group as a whole. Nevertheless, oxygen administration caused a further 19\% decrease in CI and $16 \%$ decrease in stroke index. SVR resistance increased by $23 \%$ from 27.7 to 34 units. These potentially adverse hemodynamic effects were noted in each child after 10 minutes of oxygen administration.

In the present study, $\mathrm{VO}_{2}$ decreased by $25 \%$ after 10 minutes in $95 \%$ oxygen. A similar marked decrease in $\mathrm{VO}_{2}$ has been reported during hyperbaric oxygenation. ${ }^{13}$ The mechanisms involved are unknown but one can speculate that peripheral vasoconstriction and decreased cardiac output may cause underperfusion of metabolizing tissues. In fact, the present data have shown that oxygen transport, the volume of oxygen delivered to the tissues each minute, is depressed by hyperoxia. Oxygen in high concentration may also directly inhibit oxidative metabolism. In rabbits exposed to oxygen at $3 \mathrm{~atm}$ a marked lactic acidosis develops, supporting the concept that aerobic metabolism is inhibited by hyperoxia. ${ }^{18}$

The present study has a number of potential clinical implications. First, at cardiac catheterization it is common to assess the hemodynamic response to oxygen breathing of patients with intracardiac shunts or pulmonary vascular obstructive disease. Our findings suggest that pulmonary blood flow may be overestimated and pulmonary resistance underestimated if one assumes that oxygen consumption in oxygen is the same as that measured in room air. Second, the medical and surgical therapy of children with acyanotic heart disease often includes administration of oxygen in the range of inspired oxygen concentration of 30 to $50 \%$. Thus, further investigations are warranted to determine if similar adverse hemodynamic changes occur when these therapeutic concentrations of oxygen are given.

\section{References}

1. Eggers GWN, Paley HW, Leonard $\boldsymbol{J}$, Warren JV. Hemodynamic responses to oxygen breathing in man. J Appl Physiol 1962;17:75-97.

2. Daty WJ, Bondurant S. Effects of oxygen breathing on the heart rate, blood pressure, and cardiac index of normal men-resting, with reactive hyperemia, and after atropine. J Clin Invest 1962;41:126-132.

3. Whiteborn WV, Edelmann A, Hitchcock FA. The cardiovascular responses to the breathing of 100 percent oxygen at normal barometric pressure. Am J Physiol 1946; $146: 61-65$.

4. Murray JF, Fukuda P, Jacobs P. Hemodynamic effects of 100 percent oxygen in anesthetized dogs. Clin Res 1964;12:104-110.

5. Torbati D, Parolla D, Lavy S. Organ blood flow, cardiac output, arterial blood pressure, and vascular resistance in rats exposed to various oxygen pressures. Aviat Space Environ Med 1979;March:265-263.

6. Dripps RD, Comroe JH. The effect of the inhalation of high and low oxygen concentrations on respiration, pulse rate, ballistocardiogram and arterial oxygen saturation of normal individuals. Am J Physiol 1974;149:277291 .

7. Lister G, Hoffman JIE, Rudolph AM. Oxygen uptake in infants and children: a simple method for measurement. Pediatrics 1974;53:656-661.

8. Bird AD, Felfer ABM. Effect of hyperbaric oxygen on limb circulation. Lancet Bird AD, Felfer AB

9. Hutchins PM, Bond RF, Green HD. Participation of oxygen in the local control of skeletal muscle microvasculature. Circ Res 1974;34:85-93.

10. Bergotsky EH, Bertum P. Response of regional circulations to hyperoxia. J Appl Physiol 1966;21:567-572.

11. Barratt-Boyes BF, Wood EH. Cardiac output and related measurements and pressure values in the right heart and associated vessels together with an analysis of the hemodynamic response to the inhalation of high oxygen mixtures in healthy subjects. J Lab Clin Med 1958;51:72-90.

12. Alveryd ALV, Brody S. Cardiovascular and respiratory changes in man Alveryd ALV, Brody S. Cardiovascular and respiratory changes
during oxygen breathing. Acta Physiol Scand 1948;15:140-149.

13. Jacobs RR, Willlams BT, Schenk EG. Cardiac and systemic toxicity of hyperbaric oxygen. J Thorac Cardiovasc Surg 1970;59:555-567.

14. Daniell $\mathrm{HB}$, Bagwell EE. Effects of high oxygen on coronary flow and heart force. Am J Physiol 1968;214:1454-1459.

15. Kloschos JM, Behar VS, Saltzman HA, Thompson HK, Myers NE, Smith WW, Mclntosh HD. Effect of hyperbaric oxygenation on left ventricular function. Am J Physiol 1979;216:161-166.

16. Smith G, Ledingham IM. The effect of prolonged hyperoxia on cardiovascular dynamics (abstr). Clin Sci 1970:39:12P-13P.

17. Eckenhoff JE, Hafkenschiel JH, Landmesser CM. The coronary circulation in the dog. Am J Physiol 1947;148:582-596.

18. Cassuto Y, Farhi LE. Circulatory response to arterial hyperoxia. J Appl Physiol 1979;46:973-977. 